\title{
A Numerical Study of Oceanic Circulation in San Juan, Peru. Calibration of Princeton Ocean Model During 1991-2000
}

\author{
Enrique H. Aguirre*
}

Laboratory of Modeling Methods and Computational Geophysics, PEC, COPPE, University Federal of Rio de Janeiro, CEP: 21941-596, Brazil

\begin{abstract}
The Eastern Tropical and Subtropical Pacific, particularly the coastal region of the western South America, is affected by the El Niño Southern Oscillation (ENSO) event. In this work ERS-1 and ERS-2 scatterometer data of wind stress climatology are used to study Ekman pumping/suction and transport in the coastal ocean at $15^{\circ} \mathrm{S}$ off San Juan, Peru. The Princeton Ocean Model (POM) was run to study oceanic circulation and Ekman dynamics along the Peruvian coast when La Niña (1996-1997) and El Niño (1997-1998) events occur. The model is forced by the wind stress and I use the temperature and salinity are taken from levitus climatology The analysis confirm that when strong El Niño events occur, the meridional wind stress has a dominant role in the intensity of coastal upwelling, the speed of Ekman pumping was nearly six (6) times larger than the normal speed of Ekman suction and offshore Ekman transport nearly doubled.
\end{abstract}

Keywords: Coastal upwelling, ekman pumping, humboldt current, offshore ekman transport, onshore-offshore ekman transport, princeton ocean model.

\section{INTRODUCTION}

In the coastal region of the western South America, the trade winds blow predominantly parallel to the coast making the upwelling system highly sensitive to variability in the intensity of the wind stress. The rise of coastal sea temperatures due to the weakening of coastal upwelling causes the reduction of important fish stocks and other coastal resources of economic significance, especially the sardine and anchovy populations.

The Ekman (or wind drift) layer was less than $25 \mathrm{~m}$ thick and in a direction nearly opposite to the flow beneath. Most of the biological productivity occurred within the wind-drift layer and hence tended to move upstream above the upwelling source water, possibly providing a mechanism for seeding and conditioning the upwelling water [1-2].

In the Table 3, I show the comparison between the intensity of Ekman pumping/suction, period 1997-1998, we observed that speed of Ekman pumping was nearly six (6) times larger than the normal speed of Ekman suction and offshore Ekman transport nearly doubled at $15^{\circ} \mathrm{S}$ and speed of Ekman pumping.

The coastal upwelling is especially prominent along the Peruvian coast $\left(5^{\circ} \mathrm{S}\right.$ to $\left.18^{\circ} \mathrm{S}\right)$, where alongshore winds are permanent, with a maximum in winter. Sea Surface Temperature (SST) signal of the upwelling is ambiguous at those latitudes: it is characterized by a negative zonal

*Address correspondence to this author at the Laboratory of Modeling Methods and Computational Geophysics, PEC, COPPE, University Federal of Rio de Janeiro, CEP: 21941-596, Brazil;

E-mail: enrique.huaringa@gmail.com gradient (lowest SST at the coast). The coastal winds are weak in summer but the SST gradient is great and the biological productivity is strong [4].

The most consistent and strong upwelling center on the Peruvian coast occurs near San Juan at $15^{\circ} \mathrm{S}$ where alongshore wind stress, which is representative of onshoreoffshore Ekman transport and Ekman pumping during La Niña event (1996-1997) and the El Niño event (1997-1998). In the south east Pacific, pumping effect has been locally investigated by Halpern [5]. He suggests that the strong negative Ekman pumping may be the source for the thermocline deepening at $15^{\circ} \mathrm{S}$. It has been designed to represent the ocean physics as realistically as possible depending on basin size and grid resolution [3].

The study aims to analyze the variability of marine current in the sea of Peru using data of temperature, salinity, wind stress with a grid resolution 2 . The results are obtained from the regional numerical model.

\section{METHODOLOGY}

I define the curvilinear grids [13], the grid boundary and the bathymetry (Earth Topography at 2' Resolution ETOPO2) on the finished grid. I have compiled climatologic data of wind stress [6], data of temperature and salinity climatology [8] with spatial resolution of $1^{\circ}$ and interpolated for 2'.

The principal attributes of the model are as follows [9]:

- The Model POM is a three-dimensional baroclinic nonlinear.

- It contains an imbedded second moment turbulence closure sub-model to provide vertical mixing coefficients. 
- It is a sigma coordinate model in which the vertical coordinate is scaled on the water column depth.

- The horizontal grid uses curvilinear orthogonal coordinates and an "Arakawa C" differencing scheme.

- The horizontal time differencing is explicit whereas the vertical differencing is implicit. The latter eliminates time constraints for the vertical coordinate and permits the use of fine vertical resolution in the surface and bottom boundary layers.

- The model has a free surface and a split time step. The external mode portion of the model is two-dimensional and uses a short time step based on the CourantFriedrichs-Lewy (CFL) condition and the external wave speed. The internal mode is three-dimensional and uses a long time step based on the CFL condition and the internal wave speed.

- A orthogonal curvilinear grid from $5^{\circ} \mathrm{N}$ to $45^{\circ} \mathrm{S}$ Latitude and from $125^{\circ} \mathrm{W}$ to $65^{\circ} \mathrm{W}$ longitude. The finites difference grid, consists of two open borders (north and west) and two closed (south and east). The data of temperature, salinity and winds were interpolated each 2 of resolution in each point.

The prognostic variables are the three components of the velocity field, temperature, salinity, and two quantities which characterize the turbulence kinetic energy and the turbulence macro-scale. The governing equations together with their boundary conditions are solved by finite difference techniques, a horizontally and vertically staggered lattice of grid points is used for the computations. An implicit numerical scheme in the vertical direction and a mode splitting technique in time have been adopted for computational efficiency. I compute the Ekman pumping using the equation (1) [5]:
$\mathrm{W}_{\mathrm{EK}}=\frac{\nabla \times \tau}{\rho f}+\frac{\beta \tau_{x}}{\rho f^{2}}$

where $\tau$ and $\tau_{\mathrm{x}}$ are surface wind stress and its east-west component, respectively, and $\beta$ is the latitudinal variation of the Coriolis parameter. I realize a preliminary experiment for to tune the model, and based on these results, I analyzed the variability of coastal upwelling, ocean circulation and Ekman dynamics along the Peruvian coast.

\section{RESULTS}

Near to the eastern coastline in the trade wind region, the wind stress is equator ward along the coast; the Ekman transport (ET) is pointed offshore at the western edge but zero at the Peruvian coast. Figs. (1 and 2) shows the sea surface velocity field and upward vertical velocity in the month of January during 1997 and 1998 at $15^{\circ}$ S (Figs. 1, 2).

The coastal upwelling at $15^{\circ} \mathrm{S}$ was sustained throughout January 1997 by alongshore wind stress and Ekman suction because only the cross-shore component of the wind stress was reduced.

In January of 1997 (La Niña event) at $15^{\circ} \mathrm{S}$, showed the next conditions: high velocity of sea surface $4 \times 10^{-2} \mathrm{~m} / \mathrm{s}$, low surface temperature $\left(18,0^{\circ} \mathrm{C}\right.$ to $\left.20,0^{\circ} \mathrm{C}\right)$, strong wind and intense coastal upwelling.

We also have the following environmental conditions (Table 1 and Fig. 1), the upward vertical velocity from 0 to $500 \mathrm{~m}$ depth with low vertical was $0,0001 \mathrm{~m} / \mathrm{s}$ and vertical temperature $14,5^{\circ} \mathrm{C}$ to $19,0^{\circ} \mathrm{C}$.

During January 1998 at $15^{\circ} \mathrm{S}$, the wind was consistently from the southeast and parallel to the coast, with a mean speed of about $4,1 \mathrm{~m} / \mathrm{s}$. At $15^{\circ} \mathrm{S}$ (Table 1 and Fig. 2) the

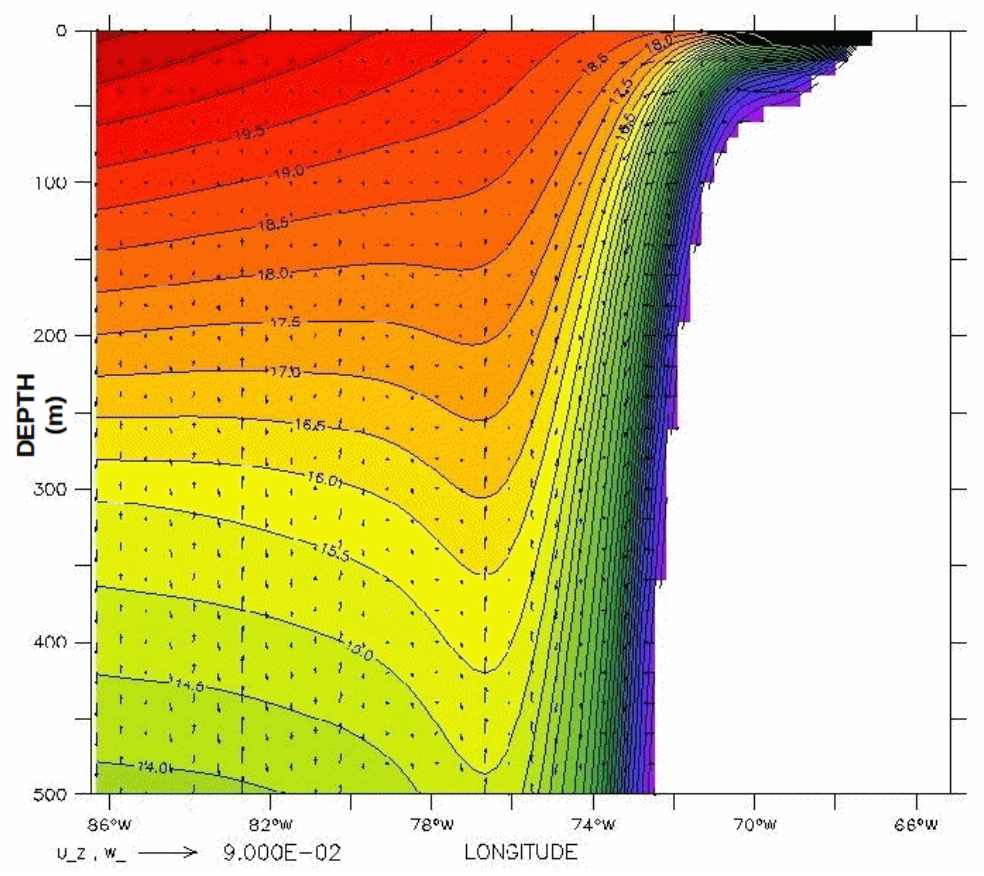

Fig. (1). Upward vertical velocity $\left(\mathrm{m} / \mathrm{s} \times 10^{-2}\right) 0-500 \mathrm{~m}$ depth at $15^{\circ} \mathrm{S}$ January 1997 . 
Table 1. El Niño (January, 1998) and La Niña (January, 1997) events.

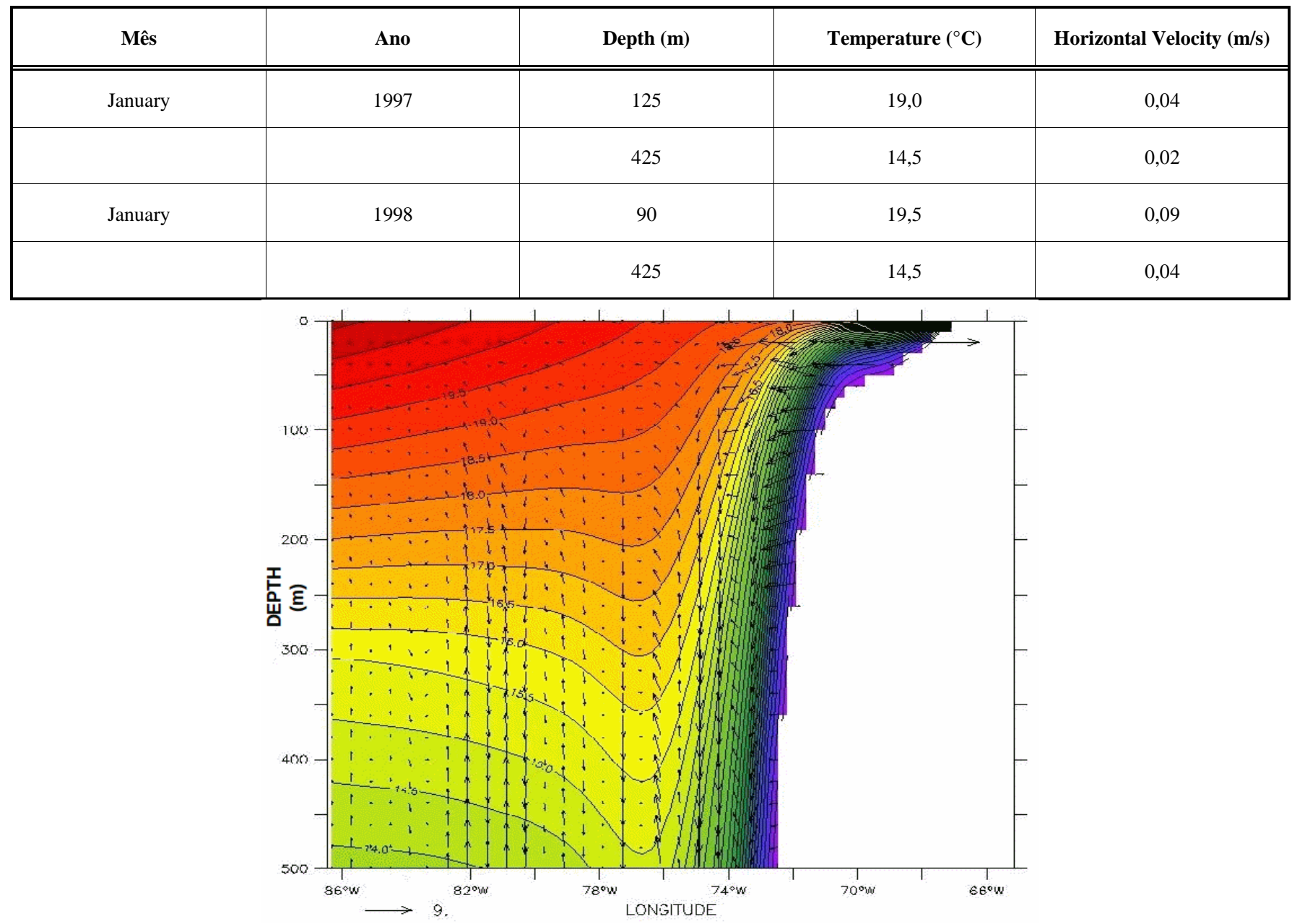

Fig. (2). Upward vertical velocity $\left(\mathrm{m} / \mathrm{s} \times 10^{-2}\right)$ 0-500 $\mathrm{m}$ depth at $15^{\circ} \mathrm{S}$ January 1998 .

upward vertical velocity from 0 to $500 \mathrm{~m}$ depth was 0,0006 $\mathrm{m} / \mathrm{s}$ and vertical temperature $14,5^{\circ} \mathrm{C}$ to $19,5^{\circ} \mathrm{C}$.

\section{DISCUSSION}

The magnitude of offshore Ekman transport component ( $x 10^{-6} \mathrm{~m}^{2} / \mathrm{s}$ ) is considered to be and index of the amount of water upwelled from the base of the Ekman layer (Fig. 4). In general, positive values are the result of equatorward wind stress. Negative values imply downwelling, the onshore advection of surface waters accompanied by a downward displacement of water [10].

The latter process may be an equally important contributor to surface Ekman divergence and upwelling [2]. The upwelling index provides an estimate of the offshore Ekman transport is computed from the large scale barometric pressure distributions (Fig. 3 and Table 2).

The sign of the offshore component of the Ekman transport, is then reversed to reflect that negative (offshore) Ekman transport leads to positive (upwelling) vertical transport, and positive (onshore)
Table 2. Years El Niño and La Niña events.

\begin{tabular}{|c|c|}
\hline ANOS & EVENTO \\
\hline \hline $1982-83$ & El Niño \\
\hline $1986-87$ & Moderate El Niño \\
\hline $1988-89$ & Strong La Niña \\
\hline $1991-92$ & Moderate El Niño \\
\hline $1994-95$ & El Niño \\
\hline $1997-98$ & Moderate El Niño \\
\hline $1998-99$ & Moderate El Niño \\
\hline $1999-00$ & Moderate El Niño \\
\hline $2002-03$ &
\end{tabular}




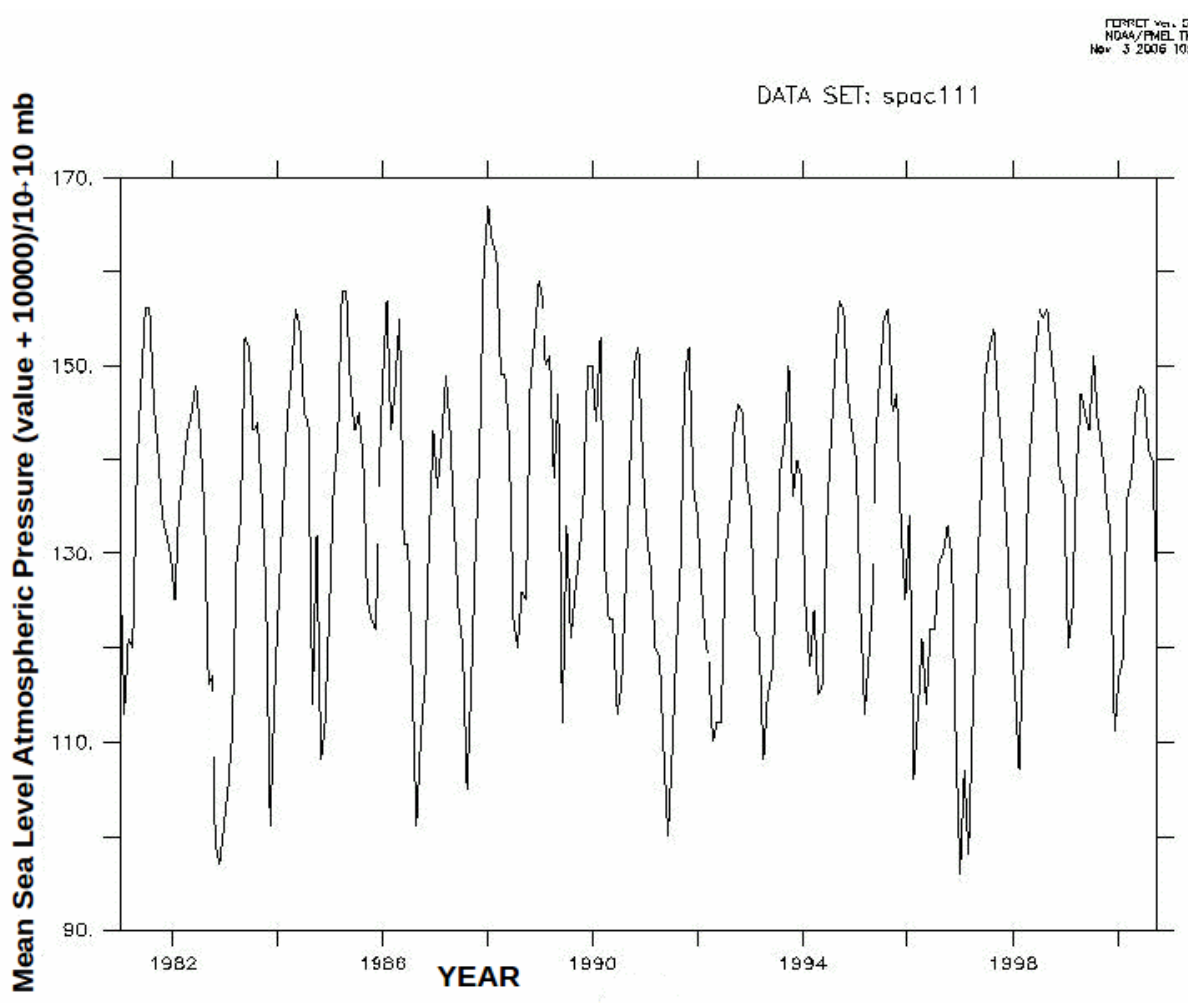

Fig. (3). Mean Sea Level Pres. (mb) 1981-2005 [7].

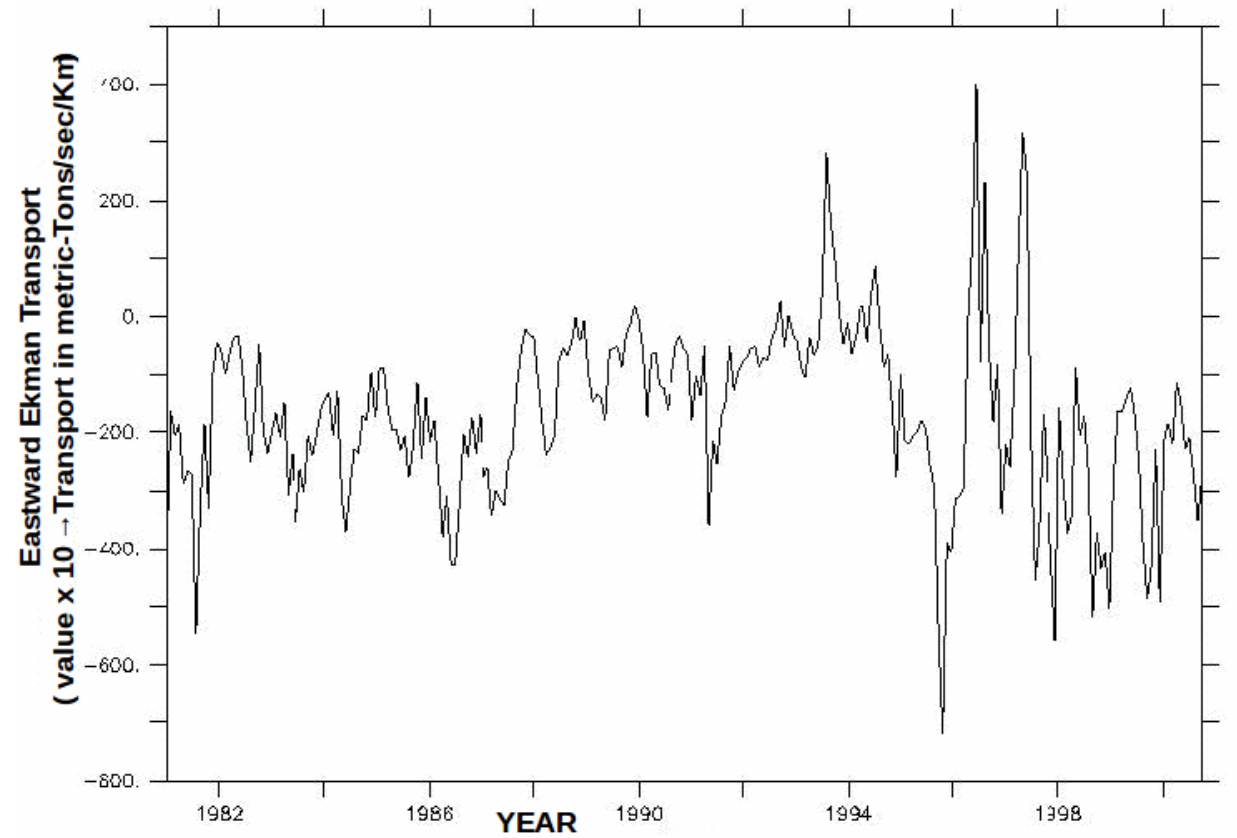

Fig. (4). Offshore Ekman transport (metric-tons/sec/100-m coast) 1981-2005.

Ekman transport leads to negative (downwelling) vertical transport (see Fig. (4) and Table 2)[1].

Upwelling is due to the combined effect of two processes: coastal upwelling and Ekman pumping or the spatial variation in the wind at $15^{\circ} \mathrm{S}$. I show the variation of intensity of wind stress curl (Fig. 5) and upward vertical velocity (Fig. 6) during El Niño and La Niña events (Table 2), from 1981 to 2005 [6-8].
One concludes that the wind-drift layer is apparently less than 25 meters deep. Below it the mean currents, and also the occurrence of the events, are essentially independent of depth and hence quasi-barotropic [11].

Reviewed observations [12] from coastal upwelling studies off Oregon, Peru, and northwest Africa. In all three regions, he found that the offshore, surface layer flow correlated well with the across-shore Ekman transport, he 


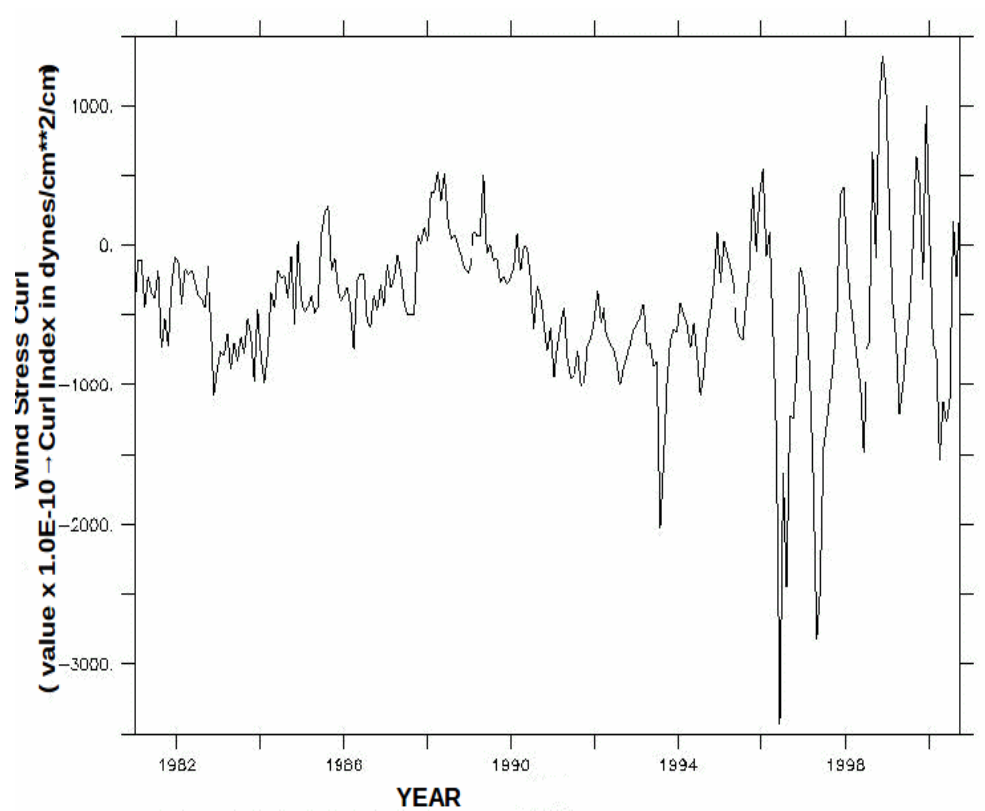

Fig. (5). Wind stress curl (dynes $\left./ \mathrm{cm}^{2} / \mathrm{cm}\right)$ 1981-2005 [7].

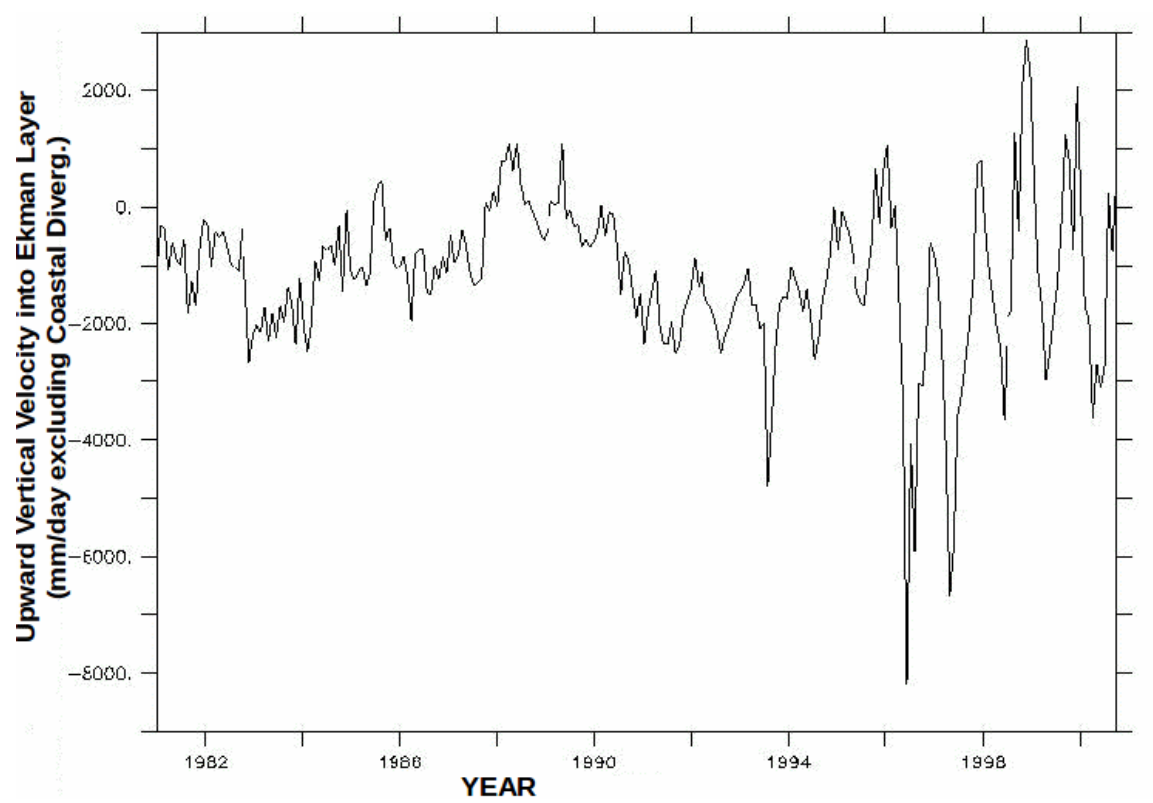

Fig. (6). Upward Vertical Velocity (mm/day), 1981-2005 [7].

Table 3. Comparison between Ekman transport and Ekman pumping at $15^{\circ} \mathrm{S}$ for January 1997 and January 1998.

\begin{tabular}{|c|c|c|}
\hline January Event 1997/1998 & Pumping Ekman $\mathbf{~} / \mathbf{s} \times \mathbf{1 0}^{-6} \mathbf{1 5} \mathbf{S}^{\circ}$ & $\mathbf{E T ~}^{\mathbf{2}} / \mathbf{s} \times \mathbf{1 0}^{-\mathbf{6}} \mathbf{1 5}^{\circ} \mathbf{S}$ \\
\hline \hline La Niña & -35 & 1,273 \\
\hline El Niño & -220 & 2,719 \\
\hline
\end{tabular}

concluded that mass balance was influenced by along shelf bathymetric variations.

\section{CONFLICT OF INTEREST}

The author confirms that this article content has no conflict of interest.

\section{ACKNOWLEDGMENTS}

I acknowledge support of CNPq-Brazil, the National Counsel of Technological and Science Development of Brazil, process $\mathrm{N}^{\circ} 141084 / 2002-2$ and Inter-American Institute for Global Change Research (IAI) through of Project SACC-CRN061. 


\section{REFERENCES}

[1] Bakun A. Coastal upwelling indices, west coast of north America, 1946-71. U.S. Dept. Commer., NOAA Tech. Rep., NMFS SSRF671, 1973; p. 103

[2] Bakun A. Nelson CS. The seasonal cycle of wind-stress curl in subtropical eastern boundary current regions. J Phys Oceanogr 1991; 21: 1815-34.

[3] Blumberg A, Mellor G. A description of a three-dimensional coastal ocean circulation model. In: HEAPS, N (ed). ThreeDimensional Coastal Ocean Models, Washington: Amer Geophys Union 1987; 4: 208.

[4] Carr M, Strub P, Thomas C, Blanco J. Evolution of 1996-1999 La Niña and El Niño conditions off the western coast South America: A remote sensing perspective. J Geophys Res 2002; 107: 2910-15.

[5] Ekman VW. On the influence of the earth's rotation on oceancurrents. Arkiv för matematik, astronomi, och fysik 1905; 2(1)1: 153.

[6] Halpern D. Offshore Ekman transport and Ekman pumping off Peru during the 1997-1998 El Niño. Geophys Res Lett 2002; 2: $191-4$

\section{C2-MUT-W-05-IF, 2002; 1: 52.}

PFEL. Monthly Mean Upwelling Indices, NOAA, Environmental Research Division, 1981-2005 period 2005.

[9] Levitus S, Boyer T. 1994. World Ocean Atlas 1994. National Oceanographic Data Center, Temperature NOAA Atlas NESDIS 3 Dept. of Commerce Ocean Climate Laboratory 1994; 1: 117.

[10] Mellor G. User's guide for a three-dimensional, primitive equation, numerical ocean model. Program in Atmospheric and Oceanic Sciences Princeton University, Princeton: NJ 08544-0710 2004; 1 56.

[11] Schwing F, O'Farrell M, Steger J. and Baltz K. Coastal upwelling indices west coast of North America 1946-1995. NOAA Technical Memorandum NMFS: NOAA-TM-NFMS-SWFSC-231 1996; 132 .

[12] Smith R. A comparison of the structure and variability of the flow field in three coastal upwelling regions: Oregon, northwest Africa, and Peru. In: Richards, F. A. (ed). Coastal Upwelling, Washington: Amer Geophys Union, 1981 p. 107-118.

[13] Wilkin JL, Hedstrom KS. Gridpak Users Guide. On: http://marine.rutgers.edu/po/gridpak.html

(C) Enrique H. Aguirre; Licensee Bentham Open.

This is an open access article licensed under the terms of the Creative Commons Attribution Non-Commercial License (http://creativecommons.org/licenses/by-nc/3.0/) which permits unrestricted, non-commercial use, distribution and reproduction in any medium, provided the work is properly cited. 